\title{
Application of GIS and Remote Sensing Technologies in Solid Waste Management: A Case Study of Nyahururu Municipality
}

\author{
Duncan Maina Kimwatu ${ }^{1}$, Martin Gitonga Ndiritu ${ }^{2}$ \\ ${ }^{1,2}$ Dedan Kimathi University of Technology, Institute of Geomatics, Geographic Information Systems and Remote sensing, \\ P.O Box 657-Nyeri, Kenya
}

\begin{abstract}
Solid waste management forms an integral part of most town management. Urban waste management has been a major problem in most Kenyan cities therefore a need for a comprehensive study utilizing remote sensing and GIS technology. An increase in commercial, residential and infrastructure development due to the population growth in Nyahururu town had been the major contributor for the solid waste menace in the town. The sprawling of unplanned informal settlements around the town had also contributed to this problem where ineffective mechanisms to deal with the resulting solid waste generated had not solved the problem conclusively. Landfill siting is a critical and rather overlooked method of sustainable management of solid waste in most Kenyan towns. Currently, Nyahururu uses an open dumping site system that has aggravated the need for proper siting of landfills. The siting process was guided by principle of eco friendliness, socially acceptable and economically feasible. The key factors that had been employed for the ultimate determination of suitable landfill locations include: proximity to road networks, proximity to drainage patterns, slope, geology, land use land cover, proximity to settlements and proximity to urban and shopping centers. GIS and Remote sensing techniques were employed to achieve the desired results. GIS-based Multi-Criteria Evaluation methodology was followed to have advantages of both GIS and Multi-Criteria Evaluation method and solved spatial decision making problems. Remotely sensed satellite imagery provided an effective platform for determination of land use land cover characteristics of the study area. Analytical Hierarchy Processes (AHP) pair-wise comparison module derived weights for all driving factors. The weighted driving factors were integrated in a GIS platform and produced landfill suitability map of Nyahururu municipality. The finding of this study showed that $9.862 \%$ of the study area was most suitable, $56.52 \%$ was moderately suitable, $6.11 \%$ was poorly suitable and $27.49 \%$ was Unsuitable/restricted.
\end{abstract}

Keywords: Analytical hierarchical process, Municipal Solid Waste, GIS-based Multi-Criteria Evaluation, landfill

\section{Introduction}

Waste can be defined as anything that is no longer useful and needs to be disposed of. In the waste management process, it is also considered to be any material that has been discarded and, as such, needs to be disposed of in an environmentally and acceptable manner. Solid waste could be defined as non-liquid and non-gaseous products of human activities, regarded as being useless [1]. Municipal solid waste (MSW) is a term usually applied to a heterogeneous collection of wastes produced in urban areas, the nature of which varies from region to region. The characteristics and quantity of the solid waste generated in a region is not only a function of the living standard and lifestyle of the region's inhabitants, but also of the abundance and type of the region's natural resources [2]. According to [3], the fundamental target of solid waste management (SWM) is to protect the health of the population, promote environmental quality, develop sustainability and provide support to economic productivity through utilization of waste as a resource.

Kenya is urbanizing at a very fast rate and as it does the problems of solid waste management are escalating. According to [4], the amount of solid waste generated is growing at an even faster rate than urbanization globally as urban residents begin to consume more and thus their tendency to waste also increases. Kenya's urban population has grown over the years and stood at 12.9 million (32\%) compared to 5.6 million( 19\%) in 1999 (Census statistics,2009) according to [5], [6], it has been projected that the amount of municipal solid waste generated in Kenya from 2000 tonnes generated per day to about 10,171 tonnes per day by the year 2015. This population growth is also witnessed in most municipalities whereby the rural to urban migration of people in search of employment and better livelihood conditions has led to this exponential rise population.

Solid waste management in Nyahururu municipality is under the Nyahururu Town Management. It is estimated that approximately 150 tonnes of solid waste is generated daily in the town. Several studies had attempted to solve the solid waste disposal menace in Nyahururu though such studies failed to provide viable solutions in terms of landfill siting for the city. Such studies did not fully utilize GIS and remote sensing technology and therefore unable to consider many of the key factors. As a result, up to date geographic data such as land use/ land cover were not included in their analysis. The application of GIS and remote sensing capabilities would be a unique advantage over other conventional study methods in determining suitable locations for landfills [7], [8].

\section{Problem statement}

Solid waste management had been cited as a major challenge faced by the Town Management office in Nyahururu. The area had been characterized by a dynamic urban sprawl that had resulted to an increase in waste generation and disposal 


\section{International Journal of Science and Research (IJSR) \\ ISSN (Online): 2319-7064}

Index Copernicus Value (2013): 6.14 | Impact Factor (2015): 6.391

practices. It was worth noting that the increase in population in the town had been largely facilitated by its strategic location, high agricultural potential and a favorable tourist destination location. Increasing pressure of population growth coupled with the investments being made such as residential and commercial infrastructure in the region had called for an urgent need to identify appropriate means to improve waste management.

Landfill was the most common mode for the disposal of solid waste in Nyahururu municipality as in most Kenyan towns. Despite these solid waste management systems, collecting and depositing in safe sites by landfill technique was the primary means of waste disposal. The municipality used an open dumping system that didn't meet the current level of solid waste generation in the area thus a need for proper planning and siting of landfills. Currently, dumping of solid waste is a common sight mainly along the roads, corners or open space. Inadequate mechanisms to collect, dispose and effectively manage the garbage generated was to be blamed for the accumulation of these waste thus posing an environmental, ecological and human health threat to the surrounding community.

Application of GIS and remote sensing provided a suitable platform in which various factors that had a direct influence on the site decision making process to be integrated in a single environment. This propelled the need for an in depth study of the current situation and come up with remedial solutions for both the long term and the short term.

\section{Study area}

Nyahururu municipality is one of the local authorities in Laikipia County in Kenya. The town is headquarter of Laikipia County. Its geographical boundaries are shared by two counties i.e. Nyandarua County and Laikipia County. The core urban center of the town was founded in 1929 following the establishment of the railway transport system through the area. Previously the town was known as Thomson falls, it has an average elevation of 2,303 m making it the highest Kenyan town and its geographic location lies between $0^{0} 02$ ' $31^{\prime}$ and $36^{\circ} 22^{\prime} 02$ '.

The physiography of Nyahururu is dominated by the Laikipia plateau covering most of the western and southern parts and is built up by several large sheets of lava flow. The geological composition of Nyahururu at large is majorly comprised of metamorphic and volcanic rocks. The metamorphic rocks are of pre Cambrian age and are the world's oldest rocks. According to the Laikipia meteorological department, the average maximum daily temperature per month varies between 22 and 27 degrees Celsius whereas the average minimum daily temperature per month varies between 9 and 13 degrees Celsius. Laikipia is on the Equator, so temperatures vary little year-round, although daily fluctuations can be marked.

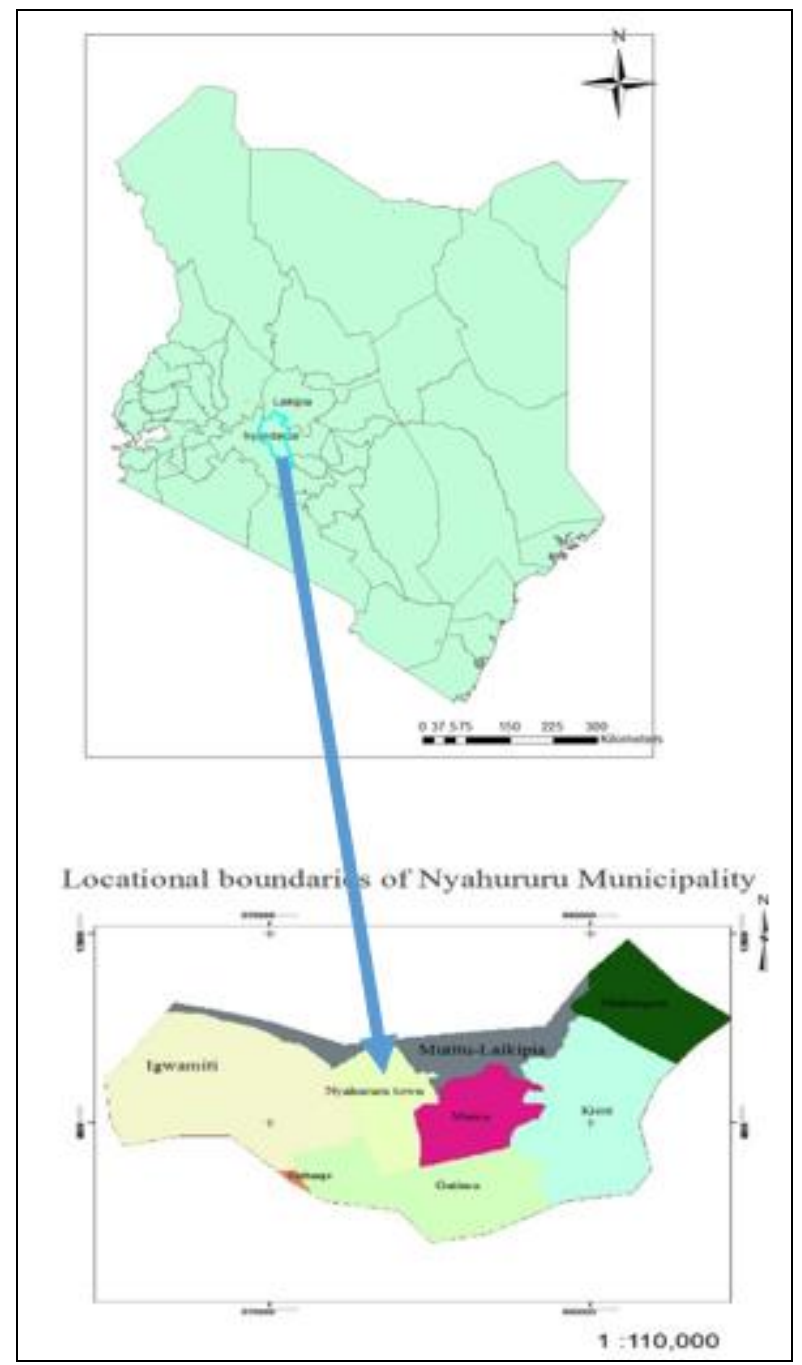

Figure 1: Nyahururu municipality and its environs

\section{Methodology}

For this research, the first step was to identify the environmental, social and economic factors that influence sites selection for landfills. Landsat 8 imagery acquired on $13^{\text {th }}$ of February 2015 was obtained from the USGS earth explorer module. One of the key characteristics of the imagery was that it had cloud cover of 0.88 that was necessary for optimum analysis. The imagery was used to generate the current land use/land cover classes of the study area. Vector data in form of shapefiles depicting the boundary extents of Nyahururu municipality were incorporated in the stacked imagery in order to generate a subset image of the study area. This was carried out on the Erdas imagine environment.

SRTM $(30 \mathrm{~m} \times 30 \mathrm{~m})$ resolution was used to extract Digital Elevation Model (DEM). The SRTM data was obtained from Global Mapper module. The DEM was used to derive slope and drainage pattern of the study area using the ArcMap module. The map showing the location boundary extents of the study area was obtained in digital format. The soil data was obtained from the Kenya soil survey datasets in form of a shapefile. The soils composition of Nyahururu municipality was then extracted. Also, the geological data 


\section{International Journal of Science and Research (IJSR) \\ ISSN (Online): 2319-7064}

Index Copernicus Value (2013): 6.14 | Impact Factor (2015): 6.391

was obtained in digital format from the Geological Survey of Kenya.

The various datasets such as road network, river network were digitized from google earth in close reference to the topographic map sheet of Nyahururu municipality. These datasets were later converted to compatible formats in ArcMap for subsequent analysis. This method was chosen as the suitable method for obtaining the different datasets as such datasets are up to date compared to the topographic maps.

All the mentioned data were collected, manipulated and analyzed in GIS environment to be used for further analysis.

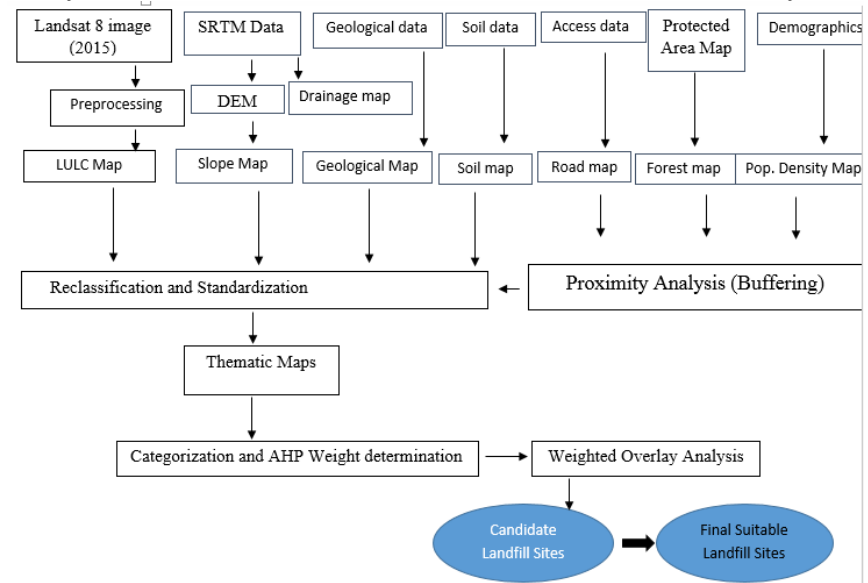

Figure 2: Methodology flow diagram adopted

The land use land cover descriptions were obtained through a supervised classification analysis of the Landsat 8 satellite imagery acquired. The imagery met the required specifications for accurate results and thus produced an accurate classified image. The land cover classes were identified as bare land, green/open land, cultivation land, forest cover and urban area/ settlements.

The methodology adopted involved integration of different datasets from different sources in the GIS environment. The different driving factor maps served as the basic input data sets for weighting and other critical processes. The methodology utilized GIS to evaluate the entire region based on certain evaluation criteria for the analysis of landfill site suitability

Proximity analysis was a critical process undertaken on some of the datasets that included drainage network, road network, Forest cover and settlements/urban locations. The criteria applied for determination of most suitable locations varied from one factor to another. It was closely referenced to some of the conventional criteria methods.

Solid landfill site selection is a complex, tedious and costly process that considers many conflicting criteria to come up with a concrete result. In this research, proximity to road, proximity to settlement, proximity to drainage networks, proximity to forested areas, slope, soil, geology and land use cover patterns were used as the core factors for analysis. The factors were classified into four classes depicting Very high, High, Moderately suitable and Poorly suitable classes. The weights for each class were derived from an online source that facilitated application of AHP methods. The method uses the expert preferences for comparing the classes and prepares a matrix table. Accordingly, weights were derived for each class giving total sum of 1 . Reclassification and weighting of the classes for each criterion considered was based certain conventional and national standards taken from different literatures.

\section{Results and Discussion}

\subsection{Proximity to Road Networks}

Landfills should not be located within $100 \mathrm{~m}$ of any major highways, city streets or other transportation routes. Solid waste dumping site must be located at suitable distance from roads network in order to facilitate transportation and consequently to reduce relative costs. In the present study by considering the two extreme, the suitability of road network classified as $0-100 \mathrm{~m}, 100-700 \mathrm{~m}, 700-1500 \mathrm{~m}, 1500-4500 \mathrm{~m}$.

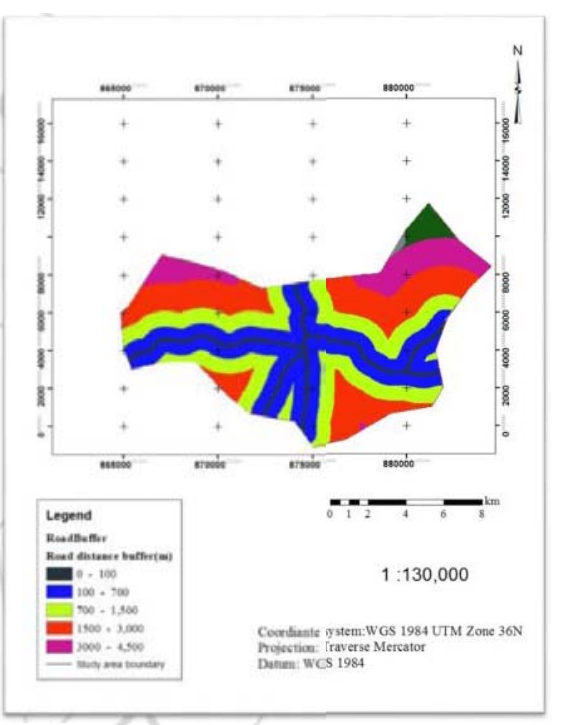

Figure 3: Suitability sites with respect to road

Table 1: Analysis of distance to road

\begin{tabular}{|l|l|l|l|c|}
\hline $\begin{array}{l}\text { Distance } \\
\text { from road }\end{array}$ & $\begin{array}{l}\text { Level of } \\
\text { suitability }\end{array}$ & Value & $\begin{array}{l}\text { Areal } \\
(\text { Sq. km) })\end{array}$ & $\begin{array}{c}\text { Area } \\
(\%)\end{array}$ \\
\hline $0-100$ & $\begin{array}{l}\text { Moderately } \\
\text { suitable }\end{array}$ & 2 & 33.24 & 26.77 \\
\hline $100-700$ & $\begin{array}{l}\text { Highly } \\
\text { suitable }\end{array}$ & 4 & 35.56 & 28.64 \\
\hline $700-1500$ & suitable & 3 & 6.62 & 5.34 \\
\hline $1500>$ & unsuitable & 1 & 48.74 & 39.25 \\
\hline
\end{tabular}

From the table 1 , it was evident that the unsuitable area covered approximately $40 \%$ of the study area. These were areas beyond $1.5 \mathrm{~km}$ from the major road networks. In addition to these areas, other area extents that area moderately suitable cover approximately $27 \%$ of the study area. These areas were closest to the roads and thus not very suitable owing to the hazardous effect to health of the public. The suitable and the highly suitable area have an augmented area of about 34\%. Generally, for areas between 100-4500m 


\section{International Journal of Science and Research (IJSR) \\ ISSN (Online): 2319-7064 \\ Index Copernicus Value (2013): 6.14 | Impact Factor (2015): 6.391}

the preference decreased with increasing distance. This was due to increased transportation cost and inaccessibility of the area. The spatial distribution of road proximity suitability map was shown in the Figure 4.

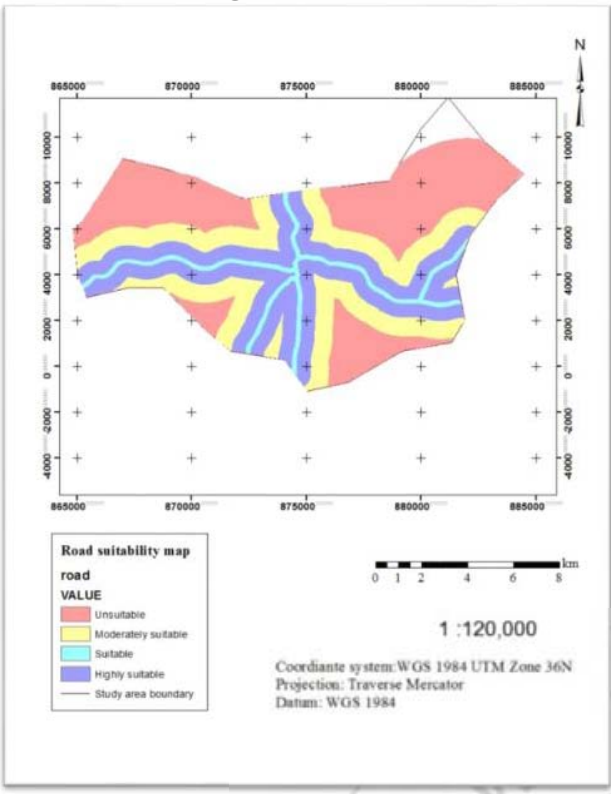

Figure 4: Road proximity suitability map

\subsection{Proximity to Drainage networks (rivers)}

In this study, $300 \mathrm{~m}$ buffer distance was used as a minimum distance from which landfill could be sited and 3000m was set as the maximum distance. Multiple Ring Buffer from Analysis Tools in ArcMap was used to prepare multiple polygons around the river networks within the following distances: 0-300m, 300-500m, 500m-1000m, 1000-3000m. Various scholars have identified that the further the distance from rivers and streams the more preferable area for landfill site. Therefore this study applies this concept accordingly. The map in figure 5 shows suitability levels and standardized thematic map of rivers/streams. This was based on reclassifying the distance to river network such that $0-300 \mathrm{~m}$ was considered unsuitable, $300 \mathrm{~m}-500 \mathrm{~m}$ was considered moderately suitable, $500 \mathrm{~m}-1000 \mathrm{~m}$ was considered suitable and beyond $1000 \mathrm{~m}$ was considered the highly suitable region.

\subsection{Proximity based on settlement}

The proximity to settlements were classified and a multi buffer analysis carried out that generated the following classed: $0-400 \mathrm{~m}, 400-900 \mathrm{~m}, 900-1500 \mathrm{~m}, 1500-2100 \mathrm{~m}$. The most suitable areas were given by the class $900-1500 \mathrm{~m}$. The distance between 400-900m was unsuitable due to its close proximity to settlements area. Reclassify tool was used and regions with distances between the following ranges i.e. 0$400 \mathrm{~m}, 400 \mathrm{~m}-900 \mathrm{~m}, 700-1500 \mathrm{~m}$ and above $1500 \mathrm{~m}$ obtained and were associated with level of suitability i.e. unsuitable, moderately suitable, highly suitable and suitable respectively. The result was as shown in figure 6 .

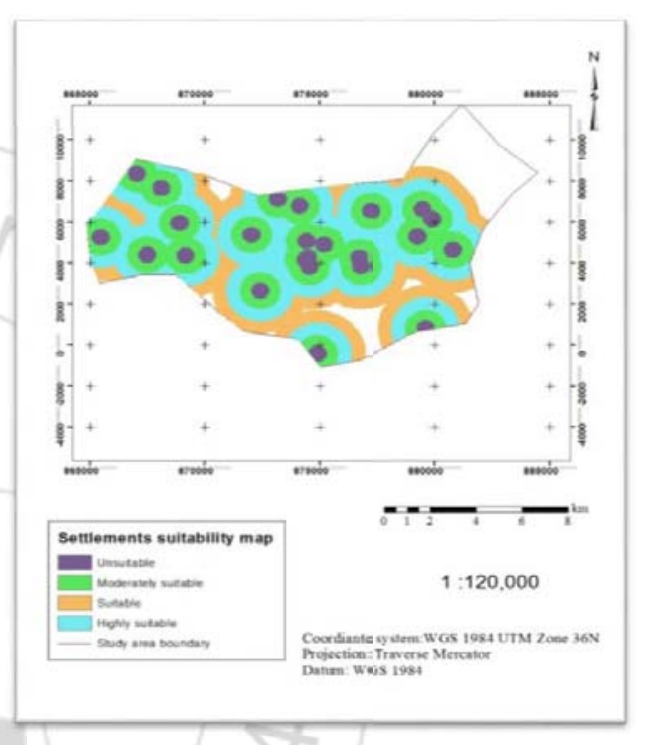

Figure 6: Reclassified distance to settlement

From figure 6, it could be observed that the most suitable areas for landfill siting are located away from the town center and rather located at the periphery of the municipality.

\subsection{Proximity based on sensitive area}

The minimum distance set for proximity analysis was 400m. A multi buffer analysis using the Multi ring buffer from the analysis tool was carried out resulting to the following four classes: $0-400 \mathrm{~m}, 400-800 \mathrm{~m}, 800 \mathrm{~m}-1200 \mathrm{~m}, 1200-2000 \mathrm{~m}$. A landfill site should be located furthest from the existing sensitive area owing to the environmental effects that might result from locating it near. Due to this the suitable area was determined as the distances in excess of $2000 \mathrm{~m}$ from the forested areas. The forest proximity map in figure 7 was generated.

Figure 5: Drainage proximity suitability map 


\section{International Journal of Science and Research (IJSR) \\ ISSN (Online): 2319-7064}

Index Copernicus Value (2013): 6.14 | Impact Factor (2015): 6.391

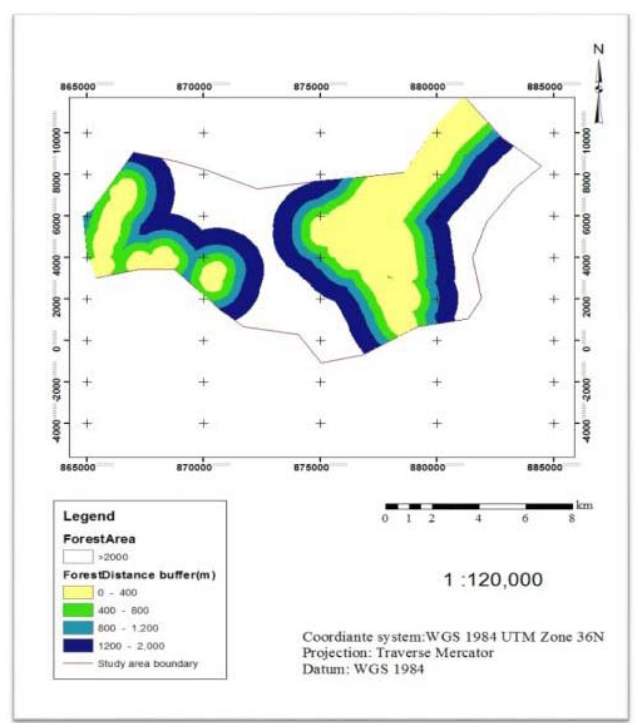

Figure 7: Forest proximity map

Figure 7 was then reclassified into four classes based on proximity distance from ecologically sensitive area i.e 0$300 \mathrm{~m}, 300-500 \mathrm{~m}, 500-1000 \mathrm{~m}$ and beyond $1000 \mathrm{~m}$. These classes were assigned level of suitability i.e unsuitable, moderately suitable, suitable, and highly suitable respectively and the results was as shown in figure 8 .

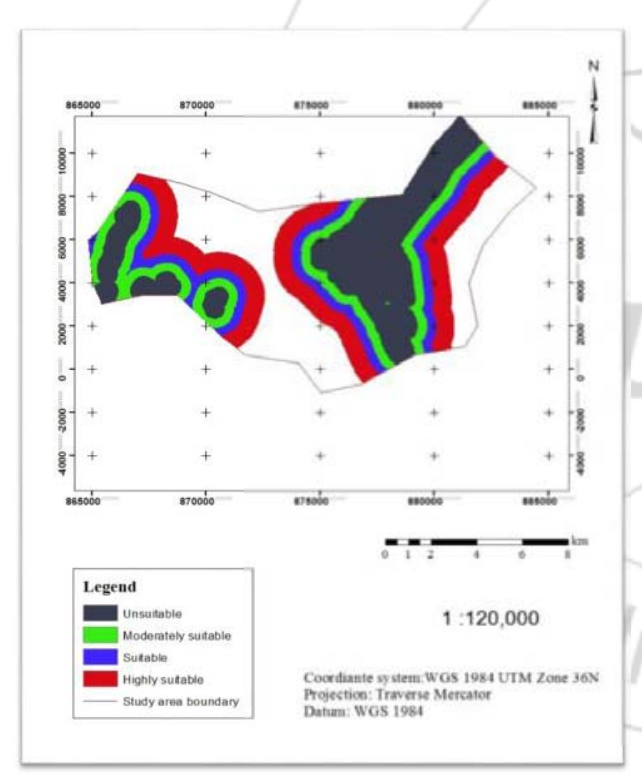

Figure 8: Reclassified proximity to sensitive areas

From the figure 8, it could be observed that a large portion of the area of study was suitable for landfill location

\subsection{Suitability based on geological conditions}

The figure 9 gives a pictorial representation of the geological composition of the area.

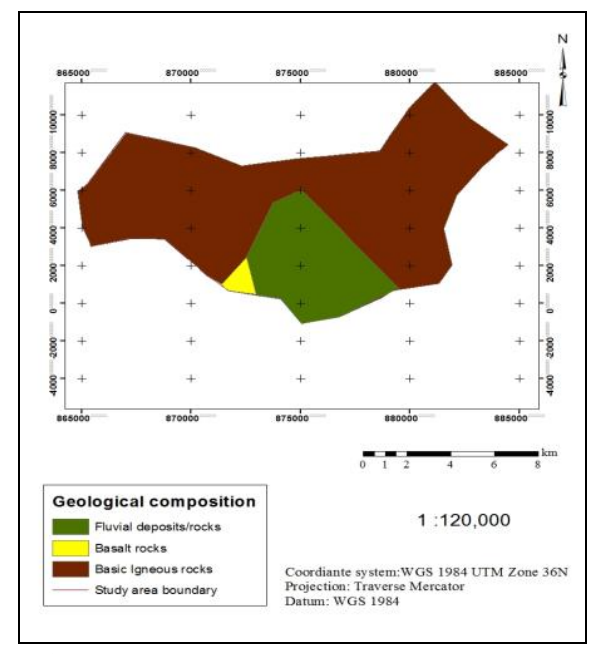

Figure 9: Geological composition

The area was comprised of Basalt lava, fluvial rocks and igneous rocks. The basalt lava area was characterized with clay with little or no sand and the soils derived from them are heavy clay. These rocks had very low permeable due to less degree of weathering and fracture and thus have a high suitability for landfill siting. The basic igneous rocks had a mineral composition of phonolites consisting of mainly of feldspar. Such rocks weather chemically to clay and also have a very low permeability due to degree of weathering and fracture. The suitability parameters of the geological composition were considered. Basalt lava which has low permeability was considered highly suitable, flucial deposits has high permeability is lowly suitable for landfills sites. Basic igneous has very low permeability thus most suitable for landfills sites. Thus figure 9, was reclassified according to the level of suitability and the result was shown in figure 10.

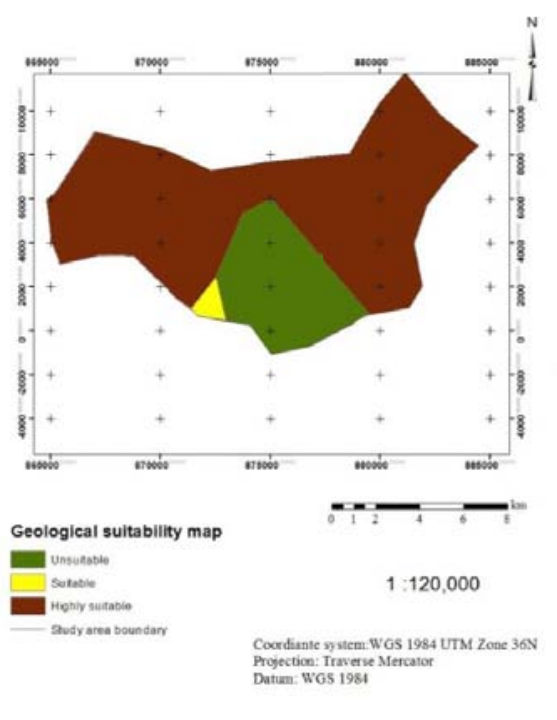

Figure 10: Reclassified geological data

Majority of the area was observed to be suitable for land fill site section. These were areas characterized by basic igneous rocks. The areas characterized by fluvial rocks determined to be highly permeable and hence unsuitable for selection. 


\subsection{Slope}

Slope of the study area was calculated from DEM (SRTM $30 \mathrm{~m} \times 30 \mathrm{~m}$ resolution) and used in GIS environment as a thematic map. The slopes were then calculated and reclassified in GIS environment. The slope values were reclassified into five classes ranging from $0-4 \%, 4-8 \%, 8-$ $15 \%, 15-24 \%$, and $24-37 \%$. The figure 11 shows the slope percentage variation of the municipality:

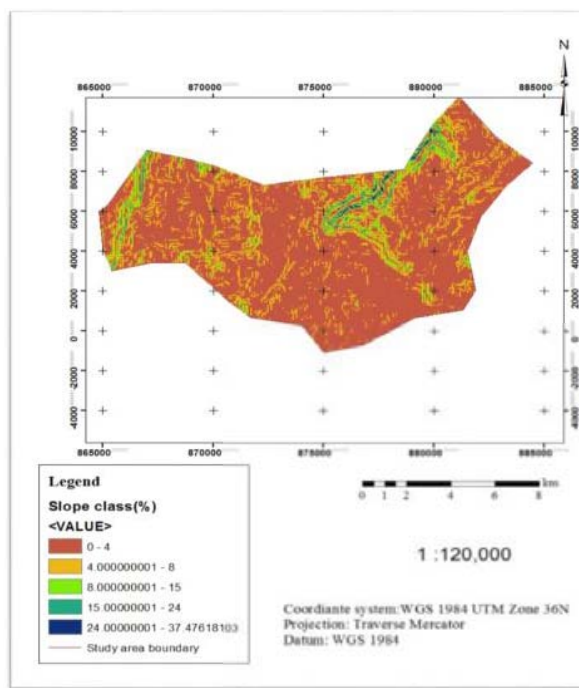

Figure 11: slope data
The topography of the area was dominated by a slope of $0-$ $4 \%$ which accounted for $72.18 \%$ of the total. It was followed by a slope of $4-8 \%$ which accounted for $20.75 \%$. The two slope classes indicate the most suitable and suitable area for landfill site selection. The $0-4 \%$ slope class indicated that the area was flat land. It was otherwise not recommended for landfill due to water logging problem and downstream surface and ground water pollution.

The steep slopes were represented by the slope class values $15-24 \%$ and $24-37 \%$. These sites were generally not suitable since they create high runoff rates for precipitation. This subjected the environment to the dangerous chemicals produced within the leachate from the landfill, especially surface waters. These sites were also not suitable due to the difficulty posed in construction or leveling, which incur additional cost during the construction phase of the landfill. Moreover, high topography areas reduces the stability of the side slopes thereby increasing the risk of landslides. Figure 11 was then reclassified as based on the suitability to landfills and the result was presented as shown in figure 12 .

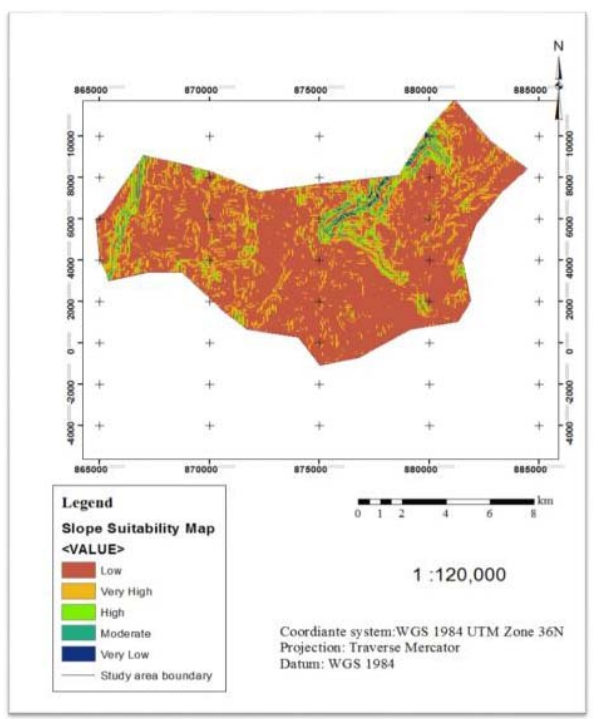

Figure 12: reclassified slope data

\subsection{Land use land cover}

Land use/land cover of the study area was obtained from satellite image (landsat8 acquired on 13-02-2015). The analysis was of great value as to determine the current land use and land cover patterns in the area. The imported sets were subsequently layer stacked to generate an image with all the required bands. To generate an image with the required study area extent, a subset procedure was carried resulting to the required Nyahururu municipality boundary. Accordingly, five land use/land cover types namely: built-up area, Cultivation land, open fields/land, forest area and bare land were identified as shown in figure 13.

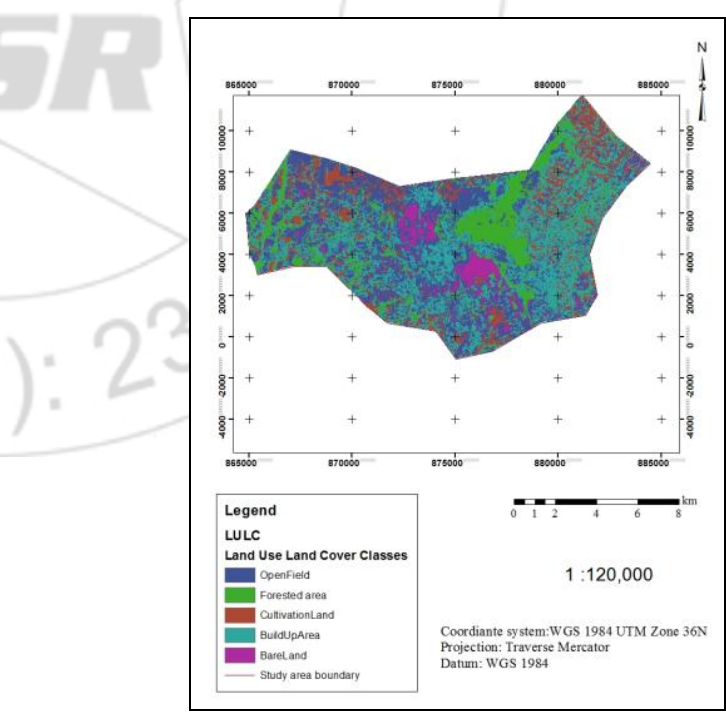

Figure 13: Land use land cover

It was clear that, open field are highly suitable for landfills, built up areas are lowly suitable, bare lands are most suitable, forested area are very lowly suitable and cultivated lands are moderately suitable, thus, reclassification on figure 13 was done and results were presented as shown in figure 14. 


\section{International Journal of Science and Research (IJSR) \\ ISSN (Online): 2319-7064}

Index Copernicus Value (2013): 6.14 | Impact Factor (2015): 6.391

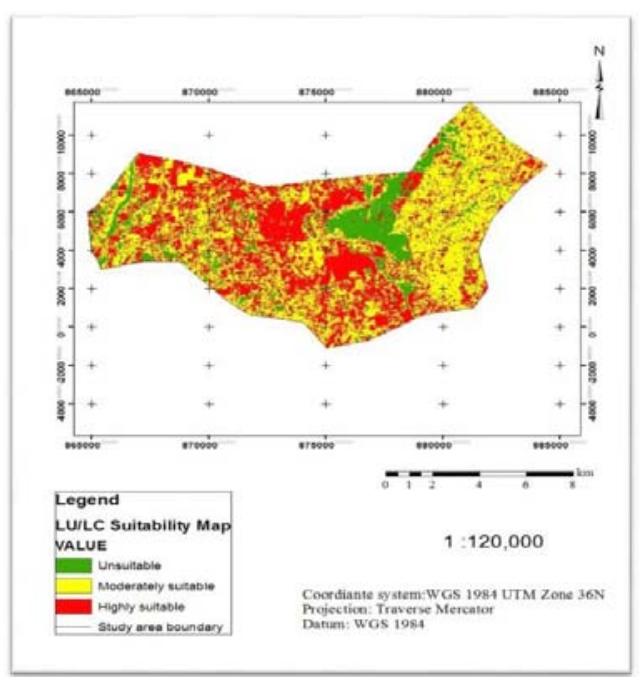

Figure 14: Reclassified land use land cover

basic criteria used for evaluating the candidate sites included determination of area size and proximity to the urban areas. Size of landfill was one of the determinant criteria for sustainable solid waste management as size of land selected for landfill determines the number of years for which the landfill will be used as a waste disposal site. It is important that the site be large enough for at least 10-15 years for economical and sustainability purposes. Such requirements are the necessary so as the cost of design, maintenance and closure can be minimized. From the figure 16, it could be deduced that the candidate landfill sites were represented

Figure 16: Candidate landfills sites

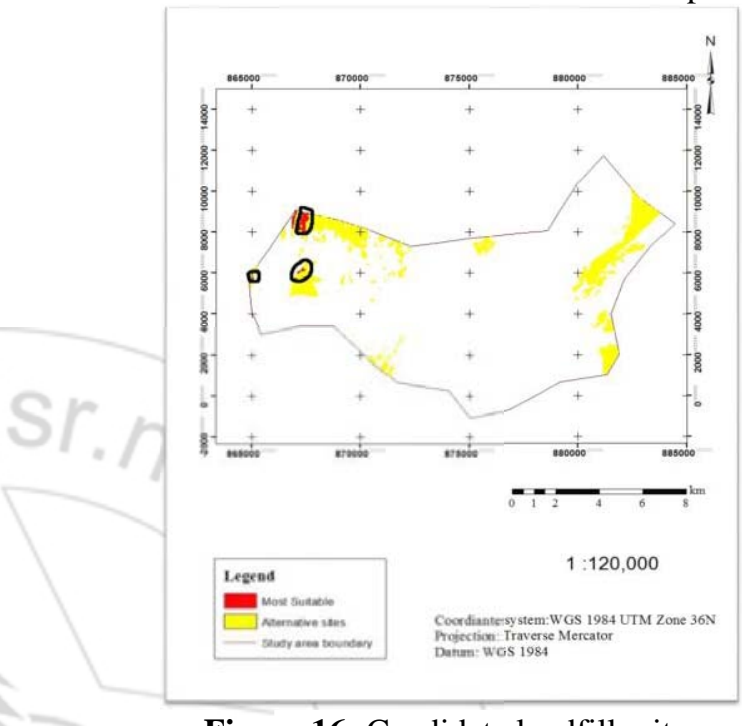
importance for they served to provide an alternative to the selection process. The candidate site described the potential areas that a site could be located. These sites might be necessary for the future requirements on solid waste management. The identified sites met the following criteria: Areas greater than $10 \mathrm{~km}^{2}$ a distance of close proximity to road networks and close proximity to Nyahururu town.

Seven suitability criteria (slope, surface water, distance from residential area (distance from urban areas), road network, soil permeability, geology and land use map) were used in this study. A final composite map was generated by weighted overlaying of the individual factor maps as shown in figure 15. From the results identified it could be observed that the majority of the land is unsuitable for selection of a landsite site. The moderately suitable area sites were of key

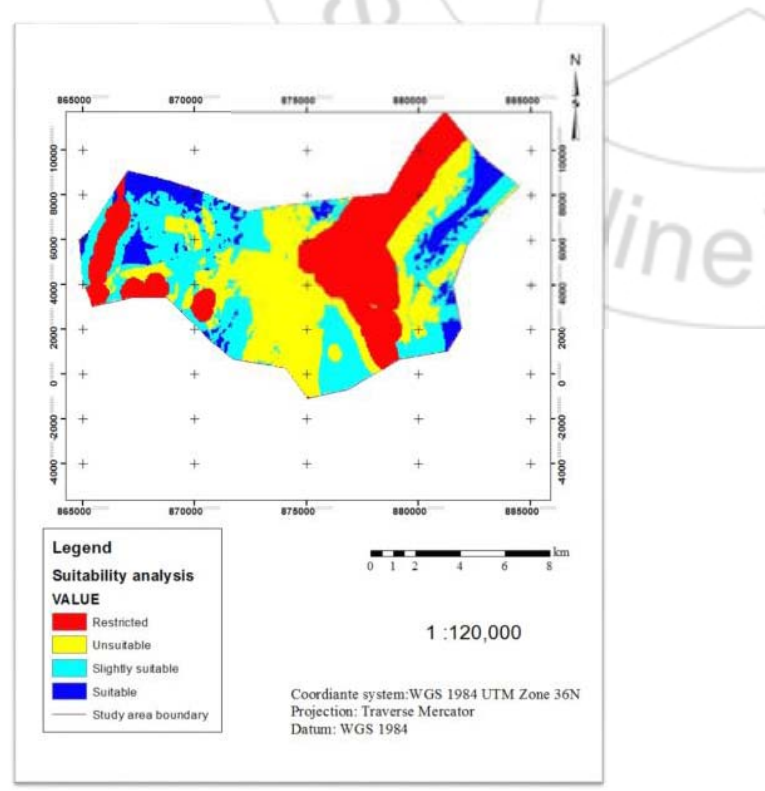

Figure 15: Land fill suitability maps

\subsection{Candidate landfills sites evaluation}

The purpose of evaluating the landfill site locations was to determine the most suitable sites with specific criteria. The
Figure 16 shows the candidate landfill site showing the most suitable area determined through a basic criteria that included determination of the area size of the present suitable site location and the proximity to the settlements and the urban area.

\section{Conclusions and Recommendation}

\subsection{Conclusion}

This study explored the capabilities of the GIS and remote sensing as a platform to guide decision making process on the selection of potential landfill sites. The environmental, physiographical and socio-economic considerations for landfill siting were of great importance during siting and technologies enabled a platform where all the individual components were analyzed. Some of the key datasets that would have adverse influence on the landfill selection process and were thereby included in the study include the proximity to drainage patterns, proximity to transportation networks, slope variations of the area, the geological composition of the area, the land use and land cover patterns of the area, proximity to forest cover and proximity to settlements and the town center. These factors were prepared as input map layers in GIS environment. The factor maps were combined according to their importance, slope and geological related factors considered having relatively more importance to have overall suitability map .The output maps were divided into four classes from unsuitable to highly suitable areas. Integration both GIS and MCDA was used for the analysis of these factor maps. The Analytic Hierarchy 


\section{International Journal of Science and Research (IJSR) \\ ISSN (Online): 2319-7064}

Index Copernicus Value (2013): 6.14 | Impact Factor (2015): 6.391

Process was applied to compare the results and check the accuracy.

The result of the final suitability map showed that $9.86 \%$ of the study area satisfied the environmental, economic and social criteria set for the site selection and hence was most suitable for landfill site. These suitable areas were identified to be in the North West and the south east parts of the study area. The unsuitable area was comprised of $6.11 \%$ of the study area. The remaining parts of $27.49 \%$ and $56.52 \%$ are suitable, highly unsuitable (restricted) and slightly suitable respectively. The best sites for landfill sites were further determined to be located in the North West part of the municipality.

\subsection{Recommendations}

The Nyahururu municipal council should ensure that the selected sites are large enough in terms of their area size preferably greater than $5 \mathrm{~km}^{2}$. This would aim at increasing its life span and reducing the cost of landfill site selection, construction and closure. The solid waste collection techniques currently in the municipality do not effectively manage these waste thus strategic positioning of solid waste containers should be done by the council apart from just enacting billboard.

The present study considers physical, environmental and socio economic factors, further study in the management of solid waste through landfill site section should be consider additional factors in order to provide more precise and comprehensive results. The Nyahururu municipal council should adopt an integrated solid waste management system (ISWM) to ensure coordination of various stakeholders in the municipals waste management systems. Adoption of associative technology in the various department is also key in order to automate the decision making process.

\section{References}

[1] Babayemi, J.O. and Dauda, K.T. (2009). Evaluation of Solid Waste Generation, Categories and Disposal Options in Developing Countries: A Case Study of Nigeria, Journal of Applied

[2] UNEP (2005). Solid Waste Management, Volume I: Part I Principles of Municipal Solid Waste Management, pp21

[3] Fides K. Kirimi, Edward H. Waithaka (2014). Determination of Suitable Landfill Site Using Geospatial Techniques and Multi-Criteria Decision Analysis: A Case Study of Nakuru Town, Kenya, International Journal of Science and Research (IJSR) 3:11, 2319-7064.

[4] Aklilu Adefris (2015). Evaluation of solid waste landfill potential site using GIS based multi criteria evaluation method: a case study of Addis Ababa, Addis Ababa University, Ethiopia, pp 5-70

[5] Nicodemus Mandere, Barry Ness and Stefan Anderberg(2010), Peri-urban development, livelihood change and household income: A case study of periurban Nyahururu, Kenya, Journal of Agricultural
Extension and Rural Development Vol. 2 (5) pp. 73-83, June, 2010

[6] UNEP (2005). Solid Waste Management, Volume I: Part I Principles of Municipal Solid Waste Management, pp21

[7] Tirusew Ayisheshim Ebistu and Amare Sewnet Minale (2013) Solid waste dumping site suitability analysis using geographic information system (GIS) and remote sensing for Bahir Dar Town, North Western Ethiopia. African Journal of Environmental Science and Technology vol 7(11), pp. 976-989 November 2013.

[8] Nishanth.T, Prakash M.N. Vijith.H (2010) Suitable site determination for urban solid waste disposal using GIS and Remote sensing techniques in Kottayam Municipality, India. International journal of Geomatics and Geosciences volume 1, No2, 2010

\section{Author Profile}

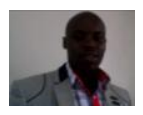

Duncan Maina is an Assistant Lecturer at Dedan Kimathi University of Technology in Nyeri County. He holds (First class Honor) degree in BSc. Geomatic Engineering and Geospatial Information Systems and a MSc. degree in GIS and Remote sensing both from JKUAT. He has a keen interest in Water Utility management, spatial security analysis, navigation, tracking system, Environmental management, Urban and regional planning, web mapping and mobile GIS applications.

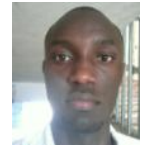

Matthew Gitonga is an alumnae of Dedan Kimathi University of Technology in Nyeri County since January 2016. He has undertaken degree in the field of Geomatics and Geospatial Information systems. He has a keen interest in Water Utility management, Solid waste management, spatial security analysis, navigation, tracking system, Environmental management, Urban and regional planning, web mapping and mobile GIS applications. 